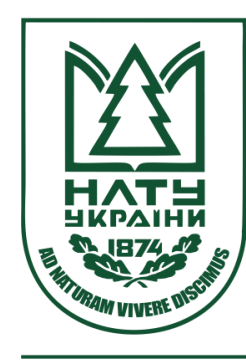

Науковий вісник НЛТУ України Scientific Bulletin of UNFU

http://nv.nltu.edu.ua

https://doi.org/10.15421/40280522

$@ \bowtie$ Correspondence author

Article received 18.05.2018 p.

Article accepted 31.05.2018 p.

S. E. Lyaskovska

УДК 621.9.048.6

М. В. Бойко, О. Т. Велика, С. Є. Лясковська, Н.-Т. І. Великий

Національний університет "Львівська політехніка", м. Львів, Україна

\title{
ДОСЛІДЖЕННЯ НАПРУЖЕНО-ДЕФОРМОВАНОГО СТАНУ ТА ОПТИМІЗАЦІЯ ГЕОМЕТРИЧНИХ ПАРАМЕТРІВ ВИРУБНОГО ПУАНСОНА
}

\begin{abstract}
Досліджено особливості напружено-деформованого стану пуансона для вирубування овальних отворів у виробах із листового матеріалу. Показано, що забезпечення надійності, міцності та безвідмовної роботи пуансона прямо залежить від рівня напружено-деформованого стану, який постійно змінюється у процесі тривалої експлуатації. Особливу увагу приділено скінченно-елементному аналізові напружено-деформованого стану конструкції пуансона, який у процесі зміни умов експлуатації руйнувався. Побудовано тривимірну модель конструкції пуансона в середовищі КОМПАС-3D, за допомогою методу скінченних елементів виконано розрахунки його параметрів, виявлено критичні області режимів роботи пуансона, в яких виникає деформація та руйнування у процесі експлуатації. Запропоновано використовувати для розрахунку пуансона прикладну бібліотеку АРM FEM, призначену для виконання обчислень твердотільних об'єктів у системі КОМПАС-3D і візуалізації одержаних результатів. Запропоновано змінити геометричні параметри конструкції пуансона та здійснити раціональний вибір типу моделі пуансона, який витримує прикладені експлуатаційні навантаження, збільшує термін його експлуатації та забезпечує ефективну роботу за надмірного навантаження у процесі вирубування овальних отворів у деталях. Результативність прийнятих проектних рішень перевірено на модернізованій моделі пуансона.
\end{abstract}

Ключові слова: пуансон; напружено-деформований стан; штамп; метод скінченних елементів.

Вступ. Листове штампування широко застосовують у багатьох галузях машинобудування. Листовим називають штампування різноманітних за формою і розмірами деталей з листового, стрічкового або смугового матеріалу. Для листового штампування, як вихідного матеріалу, використовують леговані сталі, маловуглецеві сталі, титан, мідь, алюміній та ін. Основними перевагами листового штампування $є$ :

1) можливість виготовлення міцних, легких і жорстких тонкостінних виробів простої або складної форми, отримати які іншими способами важко або неможливо;

2) висока продуктивність і економне витрачання металу;

3) широкі можливості автоматизації штампувальних робіт iз застосуванням для цього відносно нескладних пристроїв;

4) взаємозамінність деталей і висока чистота їх поверхонь.

Штамп складається 3 технологічних (робочих) i конструктивних деталей (блока) та забезпечує виконання технологічних операцій. До штампів відносять пуансони, напрямні планки, виштовхувачі, матриці, притискувачі та ін. Штампи класифікують за технологічними ознаками на штампи послідовної, простої та суміщеної дії. Для виконання кількох технологічних операцій або технологічних переходів на кількох позиціях за певне число ходів рухомої частини штампа застосовують штампи послідовної дії. Під час виконання одної або декількох однойменних технологічних операцій на одній позиції за один хід рухомої частини штампа застосовують штампи простої дії. У штампі суміщеної дії за один хід рухомої частини штампа поєднуються різнойменні технологічні операції або технологічні переходи, наприклад; вирубка та витяжка тощо.

Постановка проблеми. Пуансон або пунсон (фр. poinçon) - одна 3 основних деталей будь-якого штампу. Під час штампування пуансон безпосередньо чинить тиск на матеріал заготовки. Залежно від призначення він може бути прошивним, пробивним, просічним або вирубним. У процесі роботи пуансон передає тиск на листову заготовку, вирубує і проштовхує готовий виріб через матрицю. Він відіграє важливу роль у процесі штампування або нанесення маркувальних даних на поверхню деталі та $є$ одним 3 основних елементів технологічного оснащення будь-якого штампу. У процесі роботи пуансони піддаються впливу високих силових навантажень, тому їх виготовляють зі зносостійкої сталі 3 підвищеними міцністю і прогартованістю.

Штамп має певний термін експлуатації. Його основні деталі, пуансон та матриця, зношуються швидше, а термін експлуатації обмежений кількістю ударів пуан-

Інформація про авторів:

Бойко Михайло Васильович, ст. викладач, кафедра проектування та експлуатації машин. Email: osnastka@ukr.net Велика Оксана Тарасівна, канд. техн. наук, доцент, кафедра проектування та експлуатації машин. Email: veloks@ukr.net Лясковска Соломия Евгеньевна, канд. техн. наук, доцент кафедри проектування та експлуатації машин. Email: Solomiam@gmail.com

Великий Нестор-Тарас Ігорович, магістр, кафедра проектування та експлуатації машин. Email: veloks@ukr.net

Цитування за Дсту: Бойко М. В., Велика О. Т., Лясковська С. Є., Великий Н.-Т. І. Дослідження напружено-деформованого стану та оптимізація геометричних параметрів вирубного Пуансона. Науковий вісник НлтУ України. 2018, т. 28, № 5. С. 101-105.

Citation APA: Boyko, M. V., Velyka, O. T., Lyaskovska, S. E., \& Velykiy, N.-T. I. (2018). The researching of stress-deformed state and optimization of geometric parameters of Punch. Scientific Bulletin of UNFU, 28(5), 101-105. https://doi.org/10.15421/40280522 
сона по поверхні деталі. За зміни умов експлуатації штампу змінюються навантаження, що призводить до руйнування його основних деталей. Отже, виникає проблема дослідження і аналізу напружено-деформованого стану та зміни геометричних параметрів пуансона в процесі його експлуатації, які дають змогу запропонувати оптимальні конструкції пуансонів, що забезпечить ефективну їх роботу в разі надмірного навантаження у процесі вирубування деталі. Необхідно оптимізувати геометричні параметри пуансона в такий спосіб, щоб локалізувати критичні області, в яких виникає деформація та руйнування в процесі штампування деталей, що дасть змогу збільшити працездатність конструкції цілого штампу.

Аналіз останніх досліджень і публікацій. Проблему дослідження напружено-деформованого стану та оптимізації конструкції деталей на основі методу скінченних елементів досліджено у працях (Semepkov, 1977; Velyka, et al., 2010; Velyka \& Liaskovska, 2012). Аналіз проведених розрахунків напружено-деформованого стану пуансона у системі КОМПАС-3D та обгрунтування зміни конструкції деталі на прикладі матриці вирубного штампа наведено у роботі (Boiko, et al., 2016).

Формулювання мети дослідження. Метою роботи $\epsilon$ дослідження напружено-деформованого стану пуансона щодо виявлення проблемних ділянок, в яких можливе виникнення деформації та руйнування у процесі його експлуатації, зміни геометричних параметрів і оптимізації його конструкції.

Викладення основного матеріалу дослідження. Базовою деталлю корпусу приладу, на якому розміщуються компоненти в процесі виконання монтажних робіт, деталь "Планка". Під час виготовлення деталі "Планка" (рис. 1) штампуванням на "Штампі послідовної дії" (рис. 2) через зміну параметрів стрічкового матеріалу із сталі 08 на нержавіючу сталь змінюється навантаження i, як результат, руйнується пуансон.

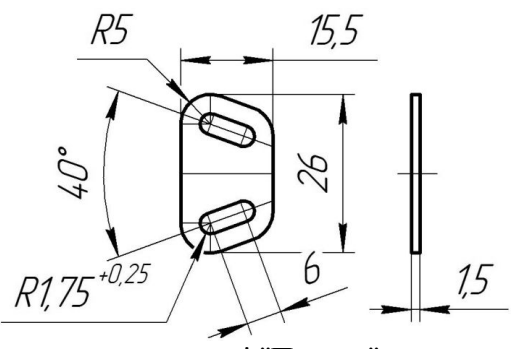

Рис. 1. Робоче креслення деталі "Планка"

Деталь виготовляють за два технологічні переходи. На першому переході пробивають два овальні отвори, а на другому переході вирубують деталь. Пуансони 8 i 9 закріплюють в пуансонотримачі 4, а знімач 3 орієнтує i направляє їх відносно матриці. Від осьового переміщення пуансони утримуються буртами, які є конструктивним елементом пуансона. Фіксацію полоси забезпечують направляючі планки 11 і 12, а фіксацію по переходах у процесі штампування здійснюють опорою 10. Лоток 13 підтримує полосу від провисання.

На пуансоні можна виділити три зони (рис. 3): $a-$ робоча, $\sigma$ - напрямна, 8 - фіксуюча. Процес пробивання отворів і вирубування деталі відбувається під час переміщення штампу зверху-вниз (робочий хід) пуансонами 8 і 9; на пуансон знизу-вверх діє сила вирубування

$$
P_{6}=L s \tau_{3 p,[\kappa \Gamma \mathrm{c}]}
$$

де: $L-$ периметр контуру, який вирубується пуансоном, мм; $s$ - товщина деталі (полоси), мм; $\tau_{\text {зр }}$ опір зрізу матеріалу, кГс/мм² і сила, необхідна для проштовхування відходу готового виробу вниз через отвори матриці.

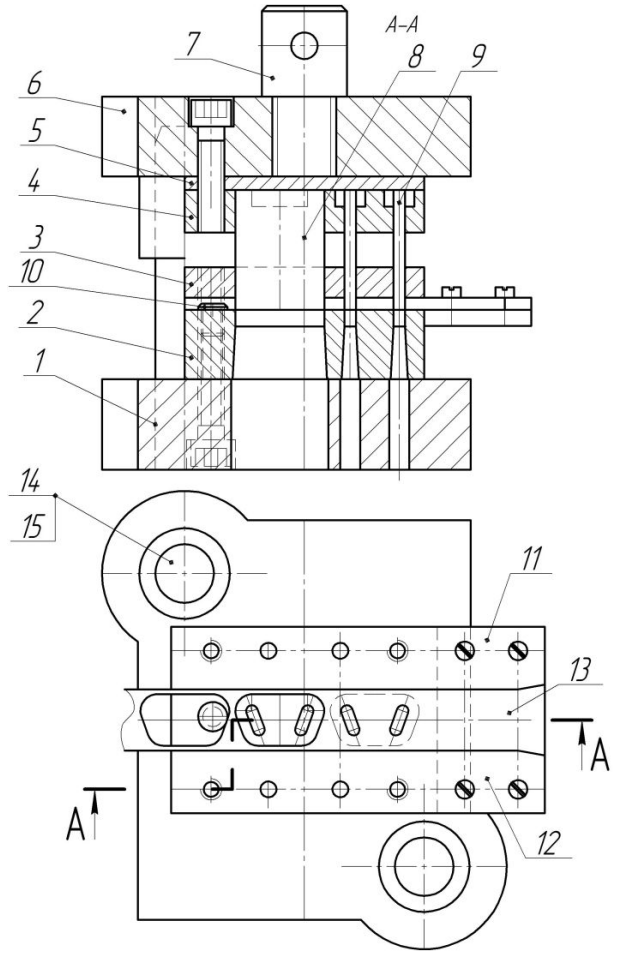

Рис. 2. Штамп послідовної дії для виготовлення деталі "Планка": 1) плита нижня; 2) матриця; 3) знімач; 4) пуансонотримач; 5) плитка; 6) плита верхня; 7) хвостовик; 8) пуансон; 9) овальний пуансон; 10) опора; 11 і 12) планки напрямні; 13) лоток; 14) колонка; 15) втулка

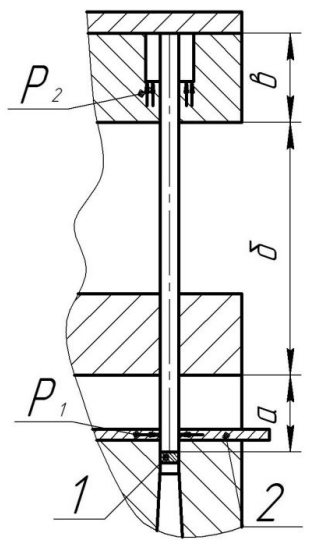

Рис. 3. Схема вирубки: 1) відхід, 2) полоса; а) робоча зона пуансона, б) напрямна зона пуансона, в) фіксуюча зона пуансона

Під дією навантаження $P_{6}$ пуансон працює на стискання. Одночасно обтискає пунсон $P_{1}$. Під час переміщення штампу знизу-верх (холостий хід) пуансон витягують із вирубаного матеріалу і на нього зверху-вниз діє сила обтиску матеріалу. Під дією цього навантаження пуансон працює на розтяг. У конструкції пуансона передбачено бурти, які утримують його від осьового переміщення в пуансонотримачі. На них діє сила, яка дорівнює силі обтискання. Під час зміни матеріалу деталі із сталі 08 на нержавіючу сталь $10 X 14 \Gamma$ змінюється сила обтискання пуансона матеріалом. Одночасно істотно збільшується навантаження на бурти, які поступово руйнуються. На рис. 4 подано робоче креслення існуючого пуансона (рис. 4,a) і зруйновані пуансони (рис. 4, б). 


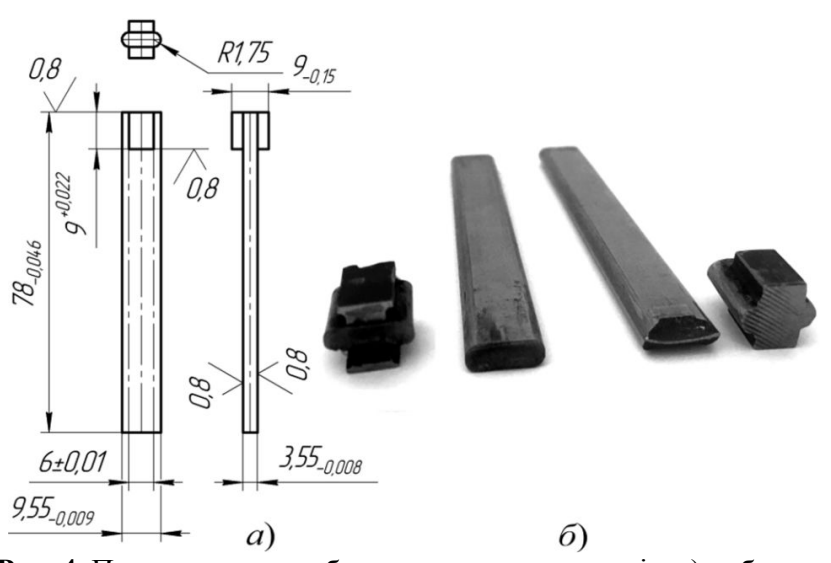

Рис. 4. Пуансон для вирубування овальних отворів: а) робоче креслення пуансона до модернізації; б) зруйновані пуансони

Для дослідження та аналізу напружено-деформованого стану вирубного пуансона використано метод скінченних елементів САЕ. Провівши розрахунки цієї конструкції пуансона методом скінченних елементів, визначимо критичні області пуансона, в яких виникає деформація та руйнування.

Метод скінчених елементів (МСКЕ, або FEM - Finite Element Method) широко використовують для розв'язування практичних завдань механіки деформованого твердого тіла, зокрема для виконання розрахунків на міцність на етапі 3D-проектування конструкцій.

Сучасні CAD-системи дають змогу в автоматичному режимі відповідно до вхідних даних виконати розрахунок моделі деталі на міцність (система вибирає вузли в об'ємі деталі, розбиває деталь на кінцеві елементи, нумерує вузли, будує матрицю елементів, складає рівняння розрахунків). Результати розрахунку відображаються у вигляді табличних даних та візуальних епюр шуканих параметрів.

Для розрахунку пуансона методом скінченних елементів використано прикладну бібліотеку АРM FEM, яку призначено для виконання розрахунків твердотільних об'єктів у системі КОМПАС-3D і візуалізації результатів цих розрахунків.

До складу АРМ FЕМ входять інструменти підготовки деталей і складань до розрахунків, задання граничних умов і навантажень, а також вбудовані генератори скінченно-елементної (СКЕ) сітки (як з постійним, так і зі змінним кроком) і постпроцесор. Цей функціональний набір допомагає змоделювати твердотільний об'єкт і комплексно проаналізувати поведінку розрахункової моделі для різних експлуатаційних задач із погляду статики, визначення власних частот коливань, стійкості й теплового навантаження тощо.

Для створення скінченно-елементного представлення об'єкта в АРM FЕМ передбачено функцію генерації СКЕ-сітки, під час виклику якої відбувається відповідне розбиття об'єкта із заданим кроком. Якщо створена розрахункова модель має складні нерівномірні геометричні переходи, то може бути проведене так зване адаптивне розбиття. Для того, щоб результат процесу був якіснішим, генератор СКЕ-сітки автоматично і з урахуванням заданого користувачем максимального коефіцієнта згущення змінює величину кроку розбиття.

Результати дослідження. Для дослідження напружено-деформованого стану пуансона побудовано в КОМПАС-3D його тривимірну модель (рис. 5).

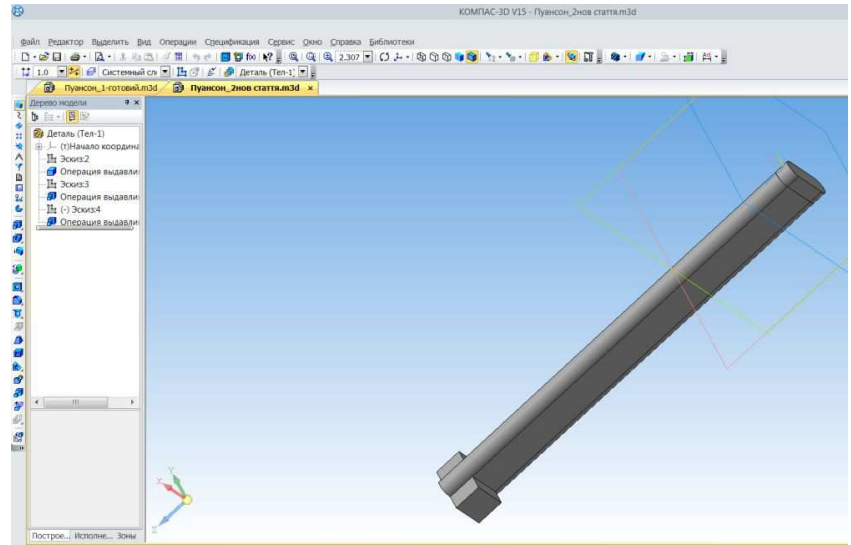

Рис. 5. 3D- модель пуансона

3D-модель пуансона розбито на елементи, запускаючи прикладну бібліотеку АРM FEM, яка знаходиться в розділі "Расчет и построение" і виконано команду Менеджера бібліотеки "Генерация КЭ сетки". Після побудови сітки проведено скінченно-елементний аналіз напружено-деформованого стану пуансона, попередньо задавши необхідні граничні умови і числові значення навантажень. Для цього виконано команду бібліотеки "Расчет" і в меню типу розрахунку вибрано "Статический расчет".

Потрібні візуалізації і аналіз результатів розрахунку представлено на рис. 6.

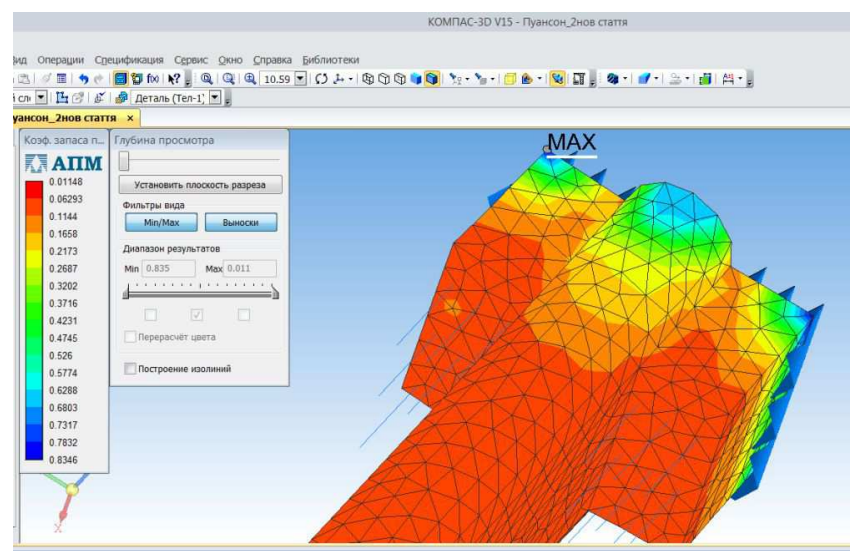

Рис. 6. Результати розрахунку на міцність 3D-моделі пуансона до модернізації

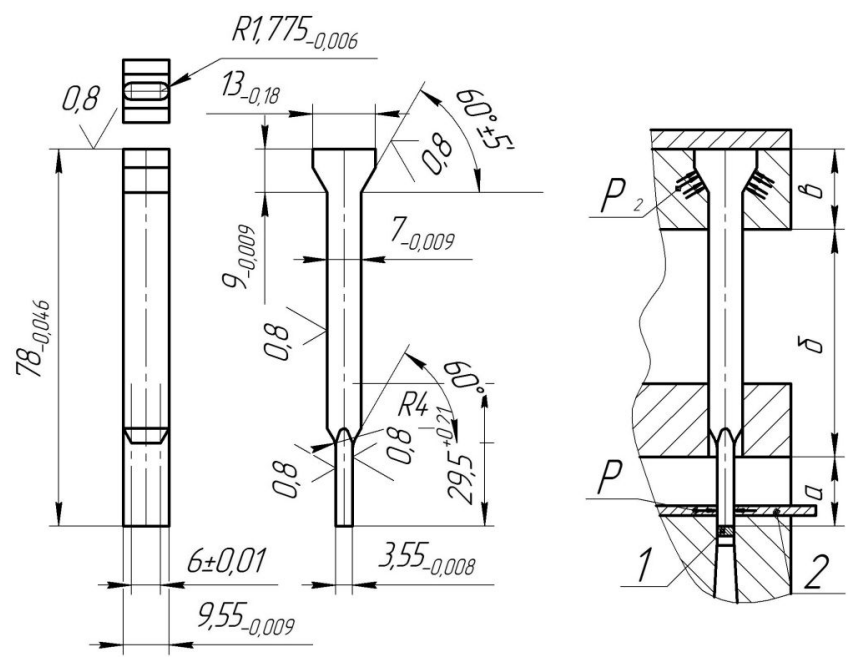

Рис. 7. Пуансон для вирубування овальних отворів: а) робоче креслення модернізованого пуансона; б) схема вирубування: 1) відхід, 2) полоса; експлуатаційні зони пуансона: а) робоча, б) направляюча, в) фіксуюча 
Аналізуючи карту результатів скінченно-елементного розрахунку напружено-деформованого стану, виявлено критичні області, в яких виникають найбільші навантаження, а отже, і можлива деформація. Тому ця ділянка пуансона часто руйнується, що призводить до зупинки виробництва. Для подолання цієї проблеми запропоновано змінити значення геометричних параметрів пуансона, врахованих у модернізованій моделі конструкції пуансона (рис. 7).

Перевірку правильності конструктивних рішень здійснено для модернізованого пуансона (рис. 8).

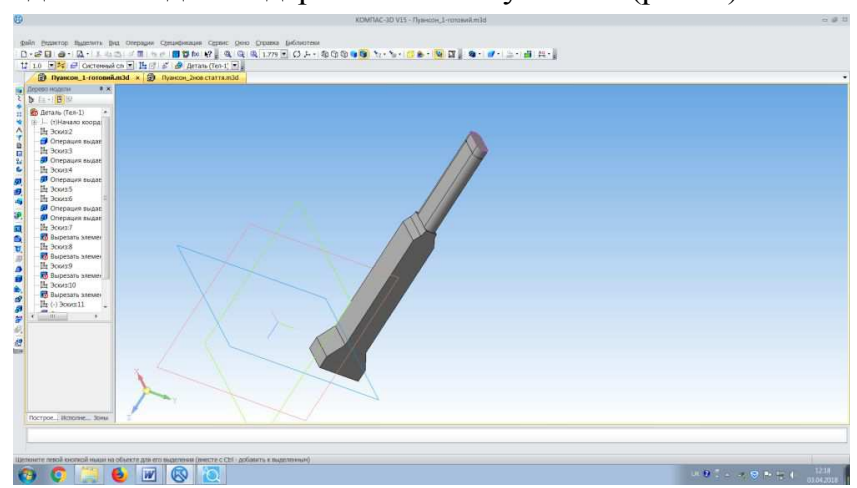

Рис. 8. 3D-модель модернізованого пуансона

У діалоговому режимі з $\mathrm{CAE} / \mathrm{CAD}$ системою виконано нові скінченно-елементні розрахунки для досягнення необхідного результату забезпечення необхідної надійності експлуатації пуансона (рис. 9).

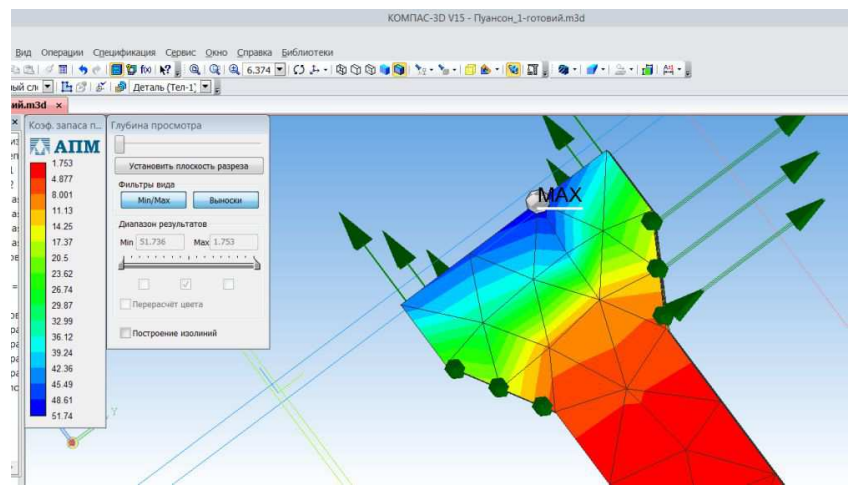

Рис. 9. Результати розрахунку на міцність 3D-моделі модернізованого пуансона
Проаналізувавши карту нових результатів розрахунків, видно, що в проблемних ділянках пуансона вдалося забезпечити міцність і стійкість до деформацій та його руйнування у процесі роботи. Це забезпечить збільшення терміну експлуатації пуансона.

Висновки. Проведено якісний і кількісний скінченно-елементний аналіз конструкції пуансона вирубного штампу, на основі якого оптимізовано геометричні параметри та розроблено покращену модель конструкції пуансона, що дає змогу забезпечити його надійну тривалу експлуатацію та працездатність.

Результати проведених досліджень напружено-деформованого стану складових деталей штампів, який змінюється у процесі тривалої їх експлуатації, відіграють визначальну роль у забезпеченні надійності, міцності та безвідмовної роботи зазначеного технологічного обладнання. При цьому важливим етапом реалізації досліджень $\epsilon$ проведення аналізу i розрахунків конструкцій робочих деталей штампів методом скінченних елементів у середовищі САЕ систем, що дає змогу оптимізувати їх геометричні параметри та здійснити раціональний вибір типу моделі пуансона, який витримує докладені експлуатаційні навантаження.

\section{Перелік використаних джерел}

Boiko, M. V., Velyka, O. T., Liaskovska, S. Ye., \& Velykyi, N.-T. I. (2016). Doslidzhennia ta optymizatsiia konstruktyvnykh parametriv matrytsi vyrubnoho shtampu. Scientific Bulletin of UNFU, 26(4), 255-260. [In Ukrainian].

Semepkov, O. I. (Ed.). (1977). Avtomatizatciia proektno-konstruktorskikh rabot i tekhnologicheskoi podgotovki proizvodstva $v$ mashinostroenii. (Vol. 2). Mynsk: Vysheishaia shkola. 334 p. [In Russian].

Velyka, O. T., \& Liaskovska, S. Ye. (2012). Optymizatsiia heometrychnykh parametriv pid chas rozrakhunkiv detalei u seredovyshchi CAD/SAE AutoCADMechanical 2006. Optymizatsiia vyrobnychykh protsesiv $i$ tekhnichnyi kontrol u mashynobuduvanni ta pryladobuduvanni, 729, 80-85. [In Ukrainian].

Velyka, O. T., Topilnytskyi, V. H., Boiko, M. V., \& Lampika, R. V. (2010). Rozrakhunok priamokutnoi matrytsi pres-formy na mitsnist i zhorstkist. Avtomatyzatsiia vyrobnychykh protsesiv v mashynobuduvanni ta pryladobuduvanni, 44, 74-79. [In Ukrainian].

М. В. Бойко, О. Т. Велыка, С. Е. Лясковска, Н.-Т. И. Велыкий

Национальный университет "Львовская политехника", г. Львов, Украина

\title{
ИССЛЕДОВАНИЕ НАПРЯЖЕННО-ДЕФОРМИРОВАННОГО СОСТОЯНИЯ И ОПТИМИЗАЦИЯ ГЕОМЕТРИЧЕСКИХ ПАРАМЕТРОВ ВЫРУБНОГО ПУАНСОННА
}

\begin{abstract}
Проведено исследование напряженно-деформированного состояния конструкции пуансона, который обеспечивает вырубку овального отверстия в изделии в процессе его изготовления с листового материала штамповкой. Обеспечение надежности, прочности и безотказной работы пуансона во многом зависит от уровня напряженно-деформированного состояния, который постоянно меняется в ходе длительной эксплуатации. Особое внимание уделено конечно-элементному анализу напряженно-деформированного состояния конструкции Пуансотна, который в процессе изменения условий эксплуатации разрушался. На первом этапе в среде КОМПАС-3D построена трехмерная модель конструкции, а дальше с помощью метода конечных элементов выполнены расчеты пуансона, обнаружены критические области пуансона, в которых возникает деформация и разрушение во время эксплуатации. Для расчета пуансона использована прикладная библиотека APM FEM, которая предназначена для выполнения расчетов твердотельных объектов в системе КОМПАС-3D и визуализации результатов этих расчетов. На основе полученных результатов предложено изменить геометрические параметры и осуществить рациональный выбор типа модели пуансона, который выдерживает приложенные эксплуатационные нагрузки, увеличивает срок его эксплуатации и обеспечивает эффективную его работу при избыточной нагрузке в процессе вырубки детали. Целесообразность принятых решений проверено на модернизированной модели пуансона.
\end{abstract}

Ключевые слова: напряженно-деформированное состояние; пуансон; штамп; метод конечных элементов. 


\section{THE RESEARCHING OF STRESS-DEFORMED STATE AND OPTIMIZATION OF GEOMETRIC PARAMETERS OF PUNCH}

The punch refers to one of the main details of the stamp. In the process of using punches are exposed to high force loads, so they are worn faster. It is necessary to optimize the geometrical parameters of the punch in such a way as to localize the critical areas in which there is deformation and destruction in the process of stamping parts, which will increase the working capacity of the design of the whole stamp. The peculiarities of the stress-strain state of the punch for the cutting of oval openings in products from sheet material have been investigated. It is shown that ensuring the reliability, durability and faultless operation of the punch directly depends on the level of the stress-strain state, which is constantly changing in the course of prolonged operation. Particular attention is paid to the finite-element analysis of the stress-strain state of the punch construction, which in the process of changing the conditions of the operation was destroyed. The 3D model of the design of the punch in the COMPASS-3D environment was constructed using the finite element method. The calculations of its parameters were used, and the critical areas of the punch were discovered. In this article, we describe the various stages of the punch in which it breaks. It is proposed to use APM application library for calculating the punch, designed to perform calculations of solid objects in the COMPASS-3D system and visualize the results obtained. The optimization of the geometrical parameters of the punch design is presented and a rational choice of the model type of the punch is carried out, which can withstand operational loads, increases the life of its operation and provides efficient work with excessive loading during the process of making the oval holes in details. The results of the researches of the stress-strain state of the components of the dies, which change in the course of their prolonged operation, play a decisive role in ensuring the reliability of, durability and trouble-free operation of the technological equipment. The effectiveness of the adopted design decisions is checked on the modernization model of the punch.

Keywords: punch; strained-deformed state; stamp; method of finite elements. 